\author{
Public Abstract \\ First Name: Tina \\ Middle Name: \\ Last Name: Varma \\ Degree: $\quad \mathrm{PhD}$ \\ Degree Program: Curriculum and Instruction \\ Adviser's First Name: Mark \\ Adviser's Last Name: Volkmann \\ Co-Adviser's First Name: \\ Co-Adviser's Last Name: \\ Graduation Term: Winter \\ Graduation Year: 2007
}

Title:

\title{
PRESERVICE ELEMENTARY TEACHERS' PERCEPTIONS OF THEIR UNDERSTANDING OF SCIENTIFIC INQUIRY-BASED PEDAGOGY AND THEIR CONFIDENCE TO TEACH SCIENCE: INFLUENCE OF ELEMENTARY SCIENCE EDUCATION METHODS COURSE AND SCIENCE FIELD EXPERIENCE
}

The purpose of this research was to determine from elementary pre-service teachers' perspectives their understanding of inquiry-based pedagogy and their confidence to teach science after concurrently completing a traditional elementary science education methods course and the associated science field experience. Results of this study indicate that when multiple inquiry-based experiences and instructional strategies, consistent with the National Science Education Standards, are integrated into a traditional elementary science methods course and reinforced through observations of classroom practice in the field, pre-service teachers develop an understanding of scientific inquiry and inquiry-based science instruction, develop an appreciation for the benefits of teaching and learning science in a constructivist environment, develop confidence to teach science and indicate intent to use inquiry-based science teaching strategies in their own classroom practice. Findings from this research study have implications for the design of the elementary education science methods course and its associated science field experience. 